\title{
Coordinate Expression of Insulin-like Growth Factor System Components by Neurons and Neuroglia during Retinal and Cerebellar Development
}

\author{
Wei-Hua Lee, Sam Javedan, and Carolyn A. Bondy \\ Developmental Endocrinology Branch, National Institute of Child Health and Human Development, Bethesda, \\ Maryland 20892
}

\begin{abstract}
The interactions of insulin-like growth factors (IGFs) with the type I IGF receptor are modulated by a family of high-affinity IGF binding proteins (IGFBPs). One of these, IGFBP2, demonstrates a striking spatiotemporal relationship with IGF-I during cerebellar and retinal development. IGF-I mRNA is transiently expressed in large projection neurons-cerebellar Purkinje and retinal ganglion cells-while IGFBP2 mRNA is selectively expressed by contiguous neurogliaBergmann glia in the cerebellum and Müller cells and astrocytes of the nerve fiber layer in the retina. IGF-I and IGFBP2 gene expression is not only neuroanatomically coordinated but also temporally synchronized, peaking together during the postnatal maturation of these structures. This pattern of IGF system expression suggests that IGFBP2 is closely related to IGF-I's action in the developing nervous system.
\end{abstract}

Insulin-like growth factors-I and -II (IGF-I and -II) are pleiotrophic polypeptides that are synthesized in a variety of tissues, including the CNS (Daughaday and Rotwein, 1989; Rechler and Nissley, 1990; LeRoith et al., in press). IGF-II is synthesized in the mesenchymal support structures (the meninges, vasculature, and choroid plexus) of the brain from their embryonic development onward, without apparent diminution (Beck et al., 1987; Stylianopoulou et al., 1988; Bondy et al., 1990). IGF-I expression in the CNS, in contrast, is highly developmentally regulated and is predominantly localized in large projection neurons of sensory and cerebellar network during a brief period in their late development (Andersson et al., 1988; Bartlett et al., 1991; Bondy, 1991). The function of IGF-I in neural development is still unknown, but the specific timing and cellular location of its expression suggest that it has a role in the differentiation of these large relay neurons (Bondy, 1991).

The actions of IGF-I arc mediatcd by the IGF-I receptor, or type I IGF receptor, which is a membrane-bound tyrosine kinase, homologous to the insulin receptor (Czech, 1989). IGF-I binding sites and IGF-I receptor $\mathrm{mRNA}$ are found in the CNS from early development (Girbau et al., 1989; Werner et al.,

\footnotetext{
Received May 4, 1992; revised June 16, 1992; accepted June 25, 1992.

We are grateful to Drs. Alexandra Brown, Matt Rechler, Haim Werner, Derek LeRoith, and Charles T. Roberts, Jr., for providing the clones used to make cRNA probes, and to Ricardo Dreyfuss for expert photomicrography. W.-H.L. is a Pharmacology Research Associate of the National Institute of General Medical Sciences.

Correspondence should be addressed to Wei-Hua Lee, NIH, Building 10, Room 10N262, 9000 Rockville Pike, Bethesda, MD 20892.

Copyright (C) 1992 Society for Neuroscience $0270-6474 / 92 / 124737-08 \$ 05.00 / 0$
}

1989; Bondy ct al., 1990). CNS IGF-I receptor expression is more extensive, both anatomically and temporally, than IGF-I expression, but during the stage of development in which there are high local levels of IGF-I production, there are high levels of IGF-I receptor synthesis localized in the same centers, including the same neurons, that synthesize IGF-I (Bondy et al., 1992). Receptor expression, as determined by autoradiographic demonstration of IGF-I binding sites, is concentrated in the local dendritic fields of the IGF-I-expressing projection neurons, for example, the molecular layer of the cerebellar cortex and glomerular layer of the olfactory bulb (Bohannon et al., 1988; Lesniak et al., 1988). These observations argue for a local, autocrine/paracrine field of action for IGF-I in nervous system development, in contrast to the target-derived mode of action proposed for NGF and related trophic factors (Barde, 1989).

IGF-I's interaction with the IGF-I receptor is regulated by a number of high-affinity IGF binding proteins (IGFBPs1-6; Clemmons, 1990; Ooi, 1990). The IGFBPs are genetically related soluble proteins that bind IGFs present in extracellular fluids. Initially, IGFBPs were regarded as passive carriers for IGFs in the bloodstream, but recently it has become apparent that they are synthesized in various different tissues in conjunction with local IGF synthesis (Wood et al., 1990; Lee et al., 1992; Chin et al., in press) and that they have complex regulatory roles in local IGF action (Elgin et al., 1987; De Mellow and Baxter, 1988; Jones et al., 1991). In order to elucidate further the local circumstances of IGF-I action in the nervous system, we have used in situ hybridization and immunohistochemistry to evaluate cellular patterns of gene expression for IGFBPs 1 and 2 during the postnatal development of the rat brain, the time when IGF-I expression is most significant. IGFBP1 mRNA was not found but IGFBP2 mRNA was abundant, and it showed a striking spatiotemporal association with IGF-I mRNA. The present study focuses on the cerebellar cortex and retina, and traces patterns of IGF-I, IGFBP2, and IGF-I receptor gene expression in the first weeks after birth.

\section{Materials and Methods}

Pregnant rats were purchased from Taconic Farms (Germantown, NY), and pups were obtained on the day of birth and at 5,12,20, and $40 \mathrm{~d}$ postnatally. Rats (males only) were killed by carbon dioxide inhalation immediately followed by decapitation. Their brains were rapidly excised, snap frozen in isopentane, and stored at $-70^{\circ} \mathrm{C}$. Brains were sectioned in $15 \mu \mathrm{m}$ thickness, thaw mounted onto poly-L-lysine-coated slides, and stored at $-70^{\circ} \mathrm{C}$ until use. Two to four brains were examined in coronal and sagittal planes for each developmental time point.

Immunocytochemistry was performed by a biotin-strepavidin-horseradish peroxidase method described elsewhere (Hsu et al., 1981). Re- 
agents for immunocytochemistry were purchased from Vector Lab (Burlingame, CA). When combined with in situ hybridization, diethylpyrocarbonate (final concentration, 0.04\%), and RNasin (180 $\mathrm{U} / \mathrm{ml}$; Promega, Madison, WI) were added to antibody, normal serum, and avidin-biotin complex. The chromogenic substrate solutions contained RNasin only. After blocking in 10\% normal horse serum, tissue sections were incubatcd overnight at $4^{\circ} \mathrm{C}$ with a $1: 50$ dilution of monoclonal antibody against vimentin (DAKO Corp., Carpinteria, CA) or a 1:5 dilution of monoclonal antibody against glial fibrillary acid protein (GFAP; Boehringer Mannheim, Indianapolis, IN). Thereafter, tissue sections were treated with biotinylated horse anti-mouse serum (1:200) for $2 \mathrm{hr}$ followed by a $45 \mathrm{~min}$ incubation with the strepavidin-peroxidase conjugate. The antigen-antibody complex was visualized by incubation with 3,3'-diaminobenzidine.

The rat IGF-I, IGF-I receptor, and IGFBP2 clones used for probe synthesis have been previously described (Bondy et al., 1990; Lee et al., 1992). The IGF-I probe contains 376 bases, complementary to sequences that encode part of the A domain, the entire $D$ and $E$ domains, and part of the $3^{\prime}$ untranslated region (Lowe et al., 1988). This probe has little homology with either the prepro-insulin or IGF-II transcripts, and shows no cross-hybridization (Lowc ct al., 1988; Bondy et al., 1990). The IGF receptor probe contains 265 bases complementary to 15 bases of $5^{\prime}$ untranslated region and to the region encoding the signal peptide and the first 33 amino acids of the $\alpha$-subunit of the rat type I IGF receptor (Werner et al., 1989). This particular region of the rat IGF-I receptor is not sufficiently homologous with the rat insulin receptor to allow any cross-hybridization between the rat type I IGF receptor probe to rat insulin receptor mRNA (Werner et al., 1989). The rat IGFBP2 clone is a 585 base fragment corresponding to nucleotides 502-1087, which does not cross-hybridize to other IGFBP mRNAs (Brown et al., 1989). The rat IGFBPI probe (kindly provided by Dr. Guck Ooi, NIDDK) was complementary to coding region nucleotides -120 to +1333 , with respect to the ATG start site.

${ }^{35}$ S-labeled cRNA probes were synthesized and used for in situ hybridization as previously described (Bondy, 1991), with the following modifications. Following immunocytochemistry, tissue sections were treated with proteinase $\mathrm{K}(1 \mu \mathrm{g} / \mathrm{ml})$ for $20 \mathrm{~min}$ at $37^{\circ} \mathrm{C}$, acetylated, delipidated, and then preincubated at $55^{\circ} \mathrm{C}$ in hybridization buffer, which was removed after $2 \mathrm{hr}$. Fresh hybridization buffer containing ${ }^{35} \mathrm{~S}$-labeled probes $\left(2 \times 10^{7} \mathrm{cpm} / \mathrm{ml}\right)$ and dithiothreitol $(100 \mathrm{mM})$ were then applied to the sections, which were incubated overnight at $55^{\circ} \mathrm{C}$, followed by stringency washes as described previously (Bondy et al., 1990). Sections were air dried and apposed to film for 2-5 $\mathrm{d}$ and then dipped in Kodak NTB2 nuclear emulsion, stored with desiccant at $4^{\circ} \mathrm{C}$ for $6-$ $15 \mathrm{~d}$, developed, and stained with cresyl violet. The level of nonspecific signal as determined by hybridization of parallel tissue sections with a "sense" probe synthesized from the IGF-I receptor clone was minimal; RNase treatment of tissue sections prior to hybridization abolished the hybridization patterns shown in this study. The IGFBPI cRNA produced a strong hybrid signal in rat liver but did not hybridize in brain or retina.

\section{Results}

IGF-I mRNA is first detected on the day of birth and accumulates to high levels in Purkinje cells during the postnatal maturation of the cerebellar cortex, reaching a peak at about postnatal day 12 (D12), after which there is a gradual decline (Fig. 1). IGFBP2 mRNA also is present in the postnatal cerebellar cortex, appearing slightly after IGF-I and peaking, like IGF-I, near the end of the second week, after which it diminishes to nearly undetectable levels by the end of the third week (Fig. 1). IGFBP2 mRNA appears to be concentrated in the Purkinje cell layer, but its distribution is more diffuse than that of IGFI. On closer inspection, it is apparent that, while IGF-I mRNA is discretely localized in Purkinje cell bodies, IGFBP2 mRNA is concentrated in smaller cells adjacent to the Purkinje cell layer (Fig. 2). IGF-I receptor mRNA is present in Purkinje cells and in most other cellular elements of the cerebellar cortex as well (Fig. 2). IGFBP2 mRNA is also abundant in the meninges throughout development and maturity (Fig. 1).

Patterns of IGF-I and IGFBP2 gene expression are similar in the maturing retina, where IGF-1 mRNA is concentrated in the ganglion cell layer, and IGFBP 2 mRNA is concentrated in the adjacent nerve fiber layer (Fig. 3). IGF-I mRNA is first detected in the ganglion cell layer a few days prior to birth, while IGFBP2 mRNA is first detected just $1 \mathrm{~d}$ before birth (on the 20th day of gestation) at which time it is confined to a small group of cells in the nerve fiber layer close to the optic disk (results not shown). At the time of birth, IGFBP2 mRNA-expressing cells extend from the optic disk about one-half of the distance to the ora serrata (Fig. 3) and by postnatal day 9 cover the entire retina (data not shown). By postnatal day 16 , IGFBP2 mRNA is no longer detectable in the retina and IGF-I mRNA is greatly diminished (not shown).

Immunocytochemical detection of GFAP was combined with in situ hybridization of IGFBP 2 m RNA in the postnatal day 12 cerebellar cortex (Fig. 4A,B). Radial Bergmann fibers show distinct GFAP staining, and IGFBP2 $\mathrm{mRNA}$ is concentrated at the base of these fibers (Fig. $4 A$ ), where the faintly GFAP-positive perikarya of the Bergmann glia are found (Fig. $4 B$ ). Since GFAP immunoreactivity is not reliably detected in retinal neuroglia, while vimentin is present in both immature astrocytes and Müller cells, we used an anti-vimentin antibody to identify neuroglia in the postnatal day 12 retina. Fusiform astrocytes and their processes surrounding axon fascicles of the nerve fiber layer show intense vimentin immunoreactivity while the slender radial fibers and Müller cells from which they arise demonstrate faint immunostaining (Fig. 4C,D). IGF-I mRNA is localized in ganglion cells, which are contacted by both astrocyte and Müller processes (Fig. $4 C$ ). IGFBP2 $\mathrm{mRNA}$ is concentrated in vimentin-positive astrocytes of the nerve fiber layer and is also localized in isolated cells in the inner nuclear layer (Fig. $4 D$ ). These cells are evenly spaced in the inner nuclear layer and show faint vimentin immunoreactivity, suggesting that they are Müller glial cells.

\section{Discussion}

We have shown that IGF-I mRNA is selectively concentrated in projection neurons and IGFBP2 mRNA in contiguous neuroglia and that their expression is synchronized during cerebellar and retinal maturation. The identification of the IGFBP2 geneexpressing cells as neuroglia is based upon their neuroanatomical location and intermediate filament staining properties. The distinctive, para-Purkinje position of the IGFBP2 mRNA-containing cells is identical to that of Bergmann radial glia in the devcloping cerebellar cortex (Bignami and Dahl, 1973; Das, 1976). Other GFAP-positive astroglial cells of the cerebellar cortex, more distant from the Purkinje cell layer, did not demonstrate IGFBP2 gene expression. In retina, the IGFBP2 mRNAcontaining cells include both radial Müller glia and fibrous astrocytes of the nerve fiber layer. The former are identified by their characteristic distribution in the inner nuclear layer and vimentin immunoreactivity. The IGFBP2 mRNA-expressing cells of the nerve fiber layer are identified as astrocytes on the basis of their morphology and vimentin immunostaining, which is seen in immature astrocytes (Schnitzer et al., 1981) and because their ontogeny is identical to that reported for this cell type (Dixon and Eng, 1981; Ling et al., 1989). Our in vivo observations on astroglial IGFBP2 gene expression are supported by a number of studies showing IGFBP2 production by cultured astroglia (Han et al., 1988; Loret et al., 1991; Olson et al., 1991).

The high-affinity IGFBPs are integrally involved in IGF-I's 

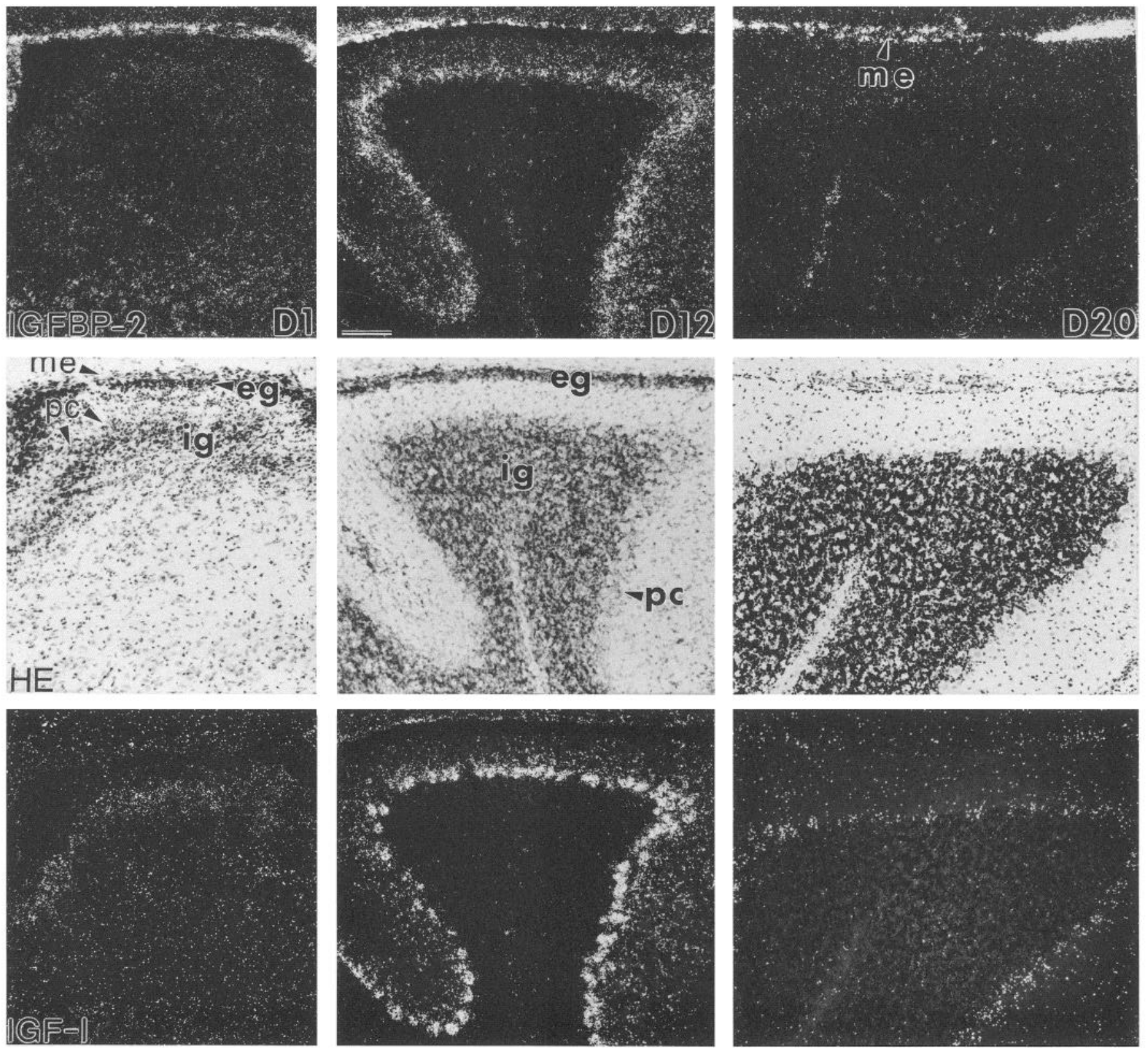

Figure 1. IGF system gene expression in the developing cerebellar cortex shown by in situ hybridization histochemistry. The top and bottom panels show dark-field illuminated, low-power micrographs of IGFBP2 and IGF-I mRNA hybrids in serial sections from anatomically matched, postnatal day $1(D 1), 12(D 12)$, and $20(D 20)$ cerebellar folia. Middle panels show corresponding bright-field illuminations. The hybridization signal appears as clusters of white grains in the dark field. IGFBP2 mRNA is abundant in the meninges covering the cerebellar surface (and external granule cell layer on D1 and D12) from birth onward, without apparent diminution. The binding protein mRNA also appears, transiently, in glial cells adjacent to Purkinje neurons, which contain IGF-I mRNA. The time course is described more fully in the text. These sections were hybridized and washed in the same incubation and exposed and developed together to allow comparison of the signal density over the succeeding developmental stages. eg, External granule cell layer; $i g$, internal granule cell layer; $m e$, meninges; $p c$, Purkinje cell layer. Scale bar, $100 \mu \mathrm{m}$.

biological mechanism of action, although the precise nature of the IGFBP modulatory role is still unclear. IGFBPs demonstrate both inhibition and potentiation of IGF-stimulated signal transduction in vitro, with the divergent results explained variously by concentration or "order of addition" effects, and by potential multimerization or phosphorylation of the IGFBPs (Elgin et al., 1987; De Mellow and Baxter, 1988; Jones et al., 1991). A number of IGFBPs, including IGFBP2, contain RGD sequences, raising the possibility that they may bind to integrin-type re- ceptors and thus target IGFs to particular sites or participate in the local organization of ligands at the cell surface.

Previous studies have shown that IGF-I immunoreactivity is localized in Purkinje cells (Hansson et al., 1988; Aguado et al., 1992) and ganglion cells (Andersson et al., 1988) during the same developmental time period in which we detect IGF-I mRNA. Ultrastructural analysis shows that IGF-I immunoreactivity is concentrated in rough endoplasmic reticulum (RER) and multivesicular bodies or lysosomes localized in Purkinje 

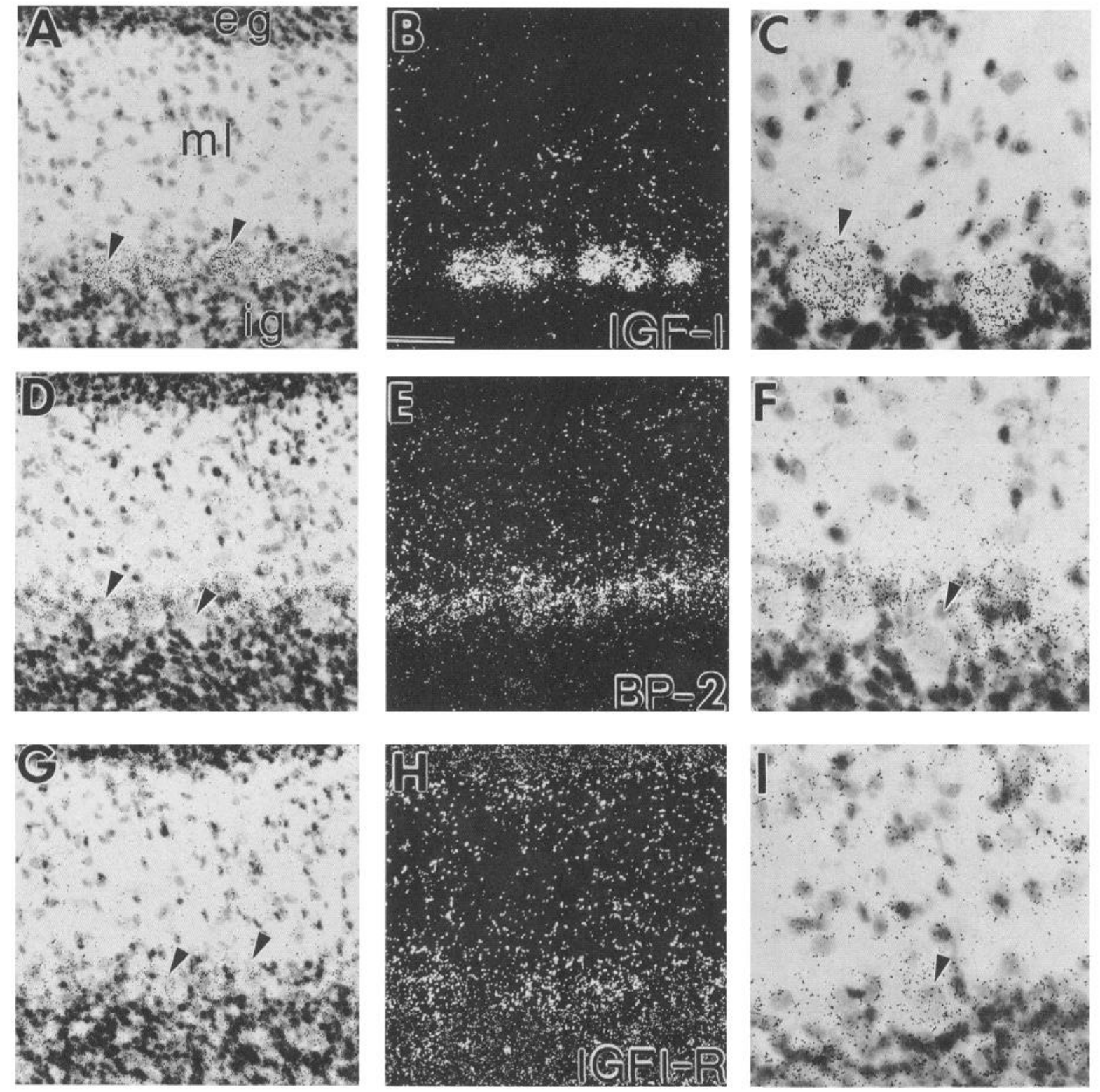

Figure 2. Comparing the cellular localization of IGF-I $(A-C)$, IGFBP2 $(D-F)$, and IGF-I receptor $(G-I)$ mRNAs in the cerebellar cortex at postnatal day 12 . $A$ and $B, D$ and $E, G$ and $H$ are paired bright and dark fields, and $C, F$, and $I$ are high-magnification micrographs of hybridization patterns for the different mRNAs. eg, external granule cell layer; ig, internal granule cell layer; $\mathrm{ml}$, molecular layer; arrowheads point to individual Purkinje cells. Scale bars: $25 \mu \mathrm{m}$ for $C, F$, and $I ; 50 \mu \mathrm{m}$ for all others.

soma and principle dendrites and is not found in neurosecretory vesicles or axons (Aguado et al., 1992). These observations provide support for the view that IGF-I is subject to constitutive release from neuronal soma and dendrites near synthetic sites in the RER, and argue against axonal transport and regulated secretion, which require packaging of the peptide in classical secretory vesicles. The finding of IGF-I immunoreactivity in Purkinje lysosomes could represent peptide-receptor complexes that have been internalized after ligand binding, and hence provides indirect evidence for an autocrine mode of action by IGF-I.

The locus of IGF-I action in the developing cerebellar cortex and retina will be determined by the anatomical site of IGF-I secretion and by local IGF-I receptor and IGFBP distribution. We have shown that IGF-I receptor mRNA is synthesized by Purkinje and ganglion cells as well as many other neural and glial cell types. Ligand-binding studies have shown that IGF-I binding sites are concentrated in the cerebellar molecular layer and retinal nuclear and internal plexiform layers-regions in which Purkinje and ganglion cell dendrites abound (Bohannon et al., 1988; Lesniak et al., 1988; Ocrant et al., 1989). Hence, it is highly likely that some of the IGF-I binding sites in these synaptic layers reside on Purkinje and ganglion cell dendrites, suggesting that IGF-I released from these cells may act in an autocrine manner. Additionally, since IGF-I receptor mRNA is also present in cerebellar granule cells, it is likely that some IGF-I binding sites in the molecular layer belong to the granule cell axons, and that IGF-I released from Purkinje cells may act in a paracrine fashion upon granule cell axonal receptors.

The production of IGFBP 2 mRNA by neuroglia in physical contact with Purkinje and ganglion cell soma and dendrites 

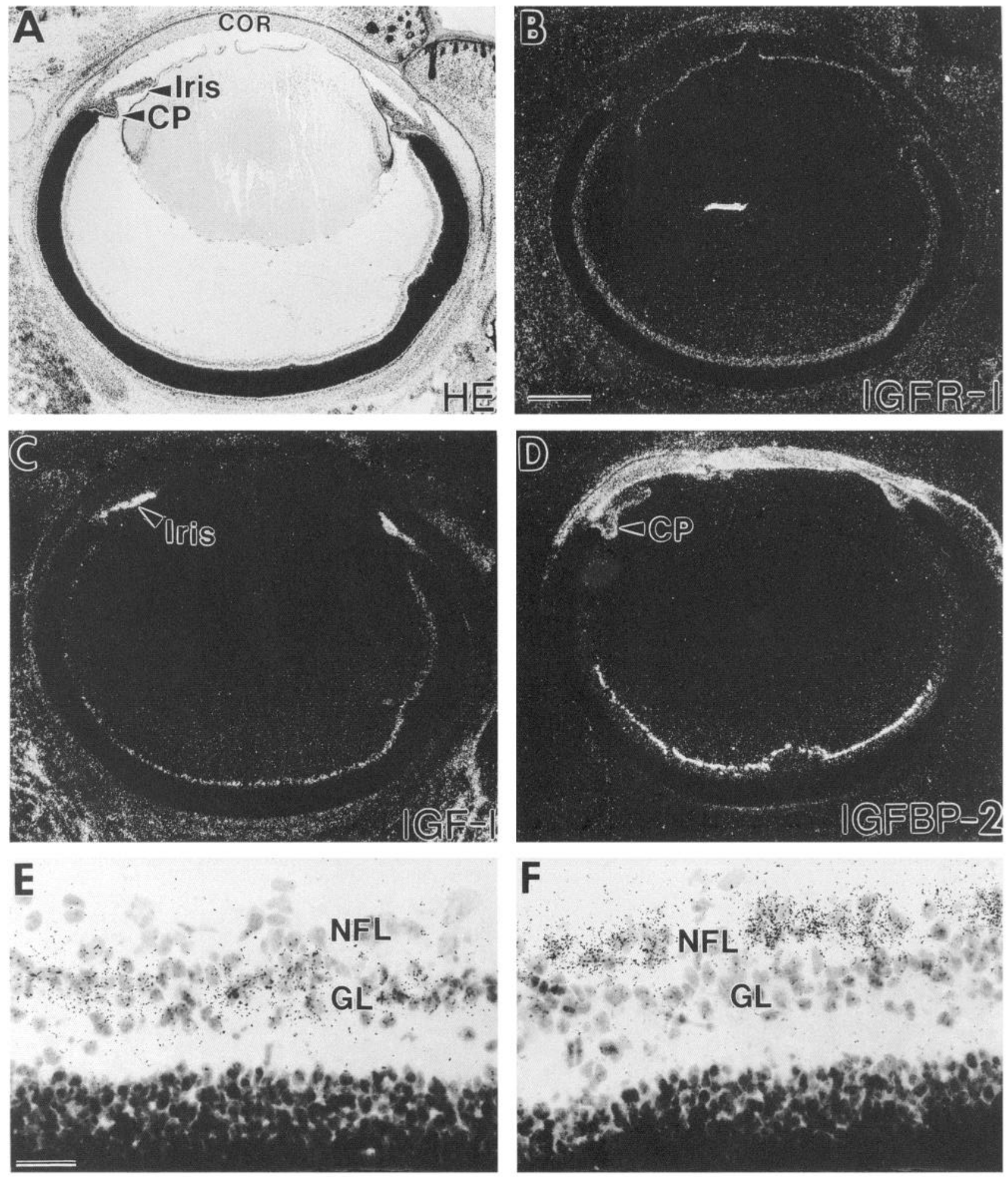

Figure 3. Ocular IGF system gene expression at the time of birth. IGF-I receptor hybridization signal $(B)$ is detected at relatively low levels, compared with that for the secreted peptides IGF-I $(C)$ and IGFBP2 $(D)$. It is present in most ocular tissues, including the anterior lens epithelium (arrowheads), ganglion cell and nerve fiber layers, and other retinal cell layers. The Nissl staining is so intense in the deeper retinal layers, however, that the dark-field signal is almost completely quenched, and the grains are difficult to photograph even in high-magnification bright field. IGF-I mRNA is concentrated in the ganglion cell layer $(C$ and $E)$ and is also abundant in the iris. IGFBP2 mRNA is concentrated in the retinal nerve fiber layer, and is also highly abundant in the corneal and ciliary process epithelium. $C O R$, cornea; $C P$, ciliary process; $G L$, ganglion cell layer; $N F L$, nerve fiber layer. Scale bars: $A-D, 4.5 \mathrm{~mm} ; E$ and $F, 25 \mu \mathrm{m}$. 

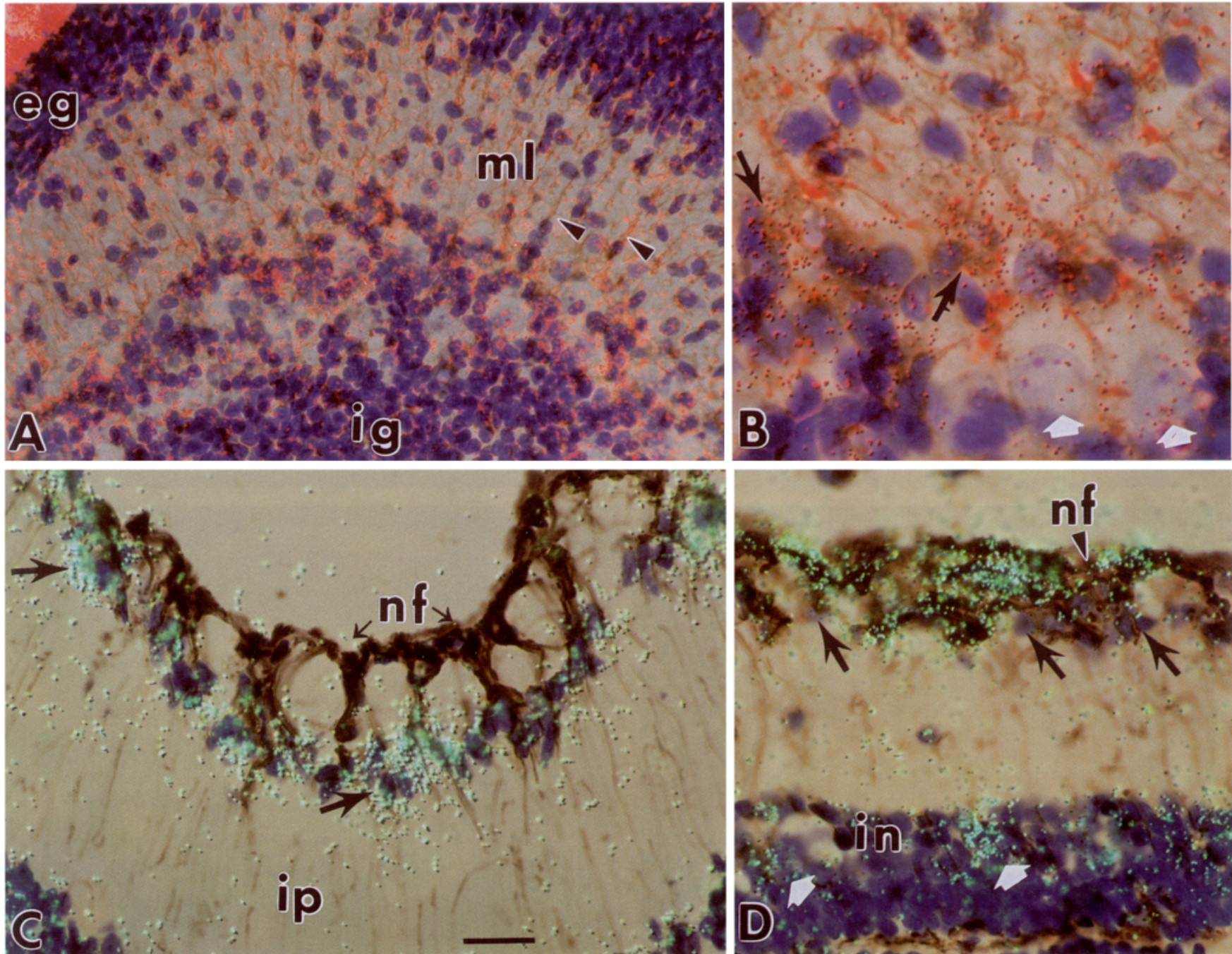

Figure 4. Combination immunocytochemistry for glial intermediate filaments and in situ hybridization in the postnatal day 12 cerebellar cortex $(A$ and $B)$ and retina $(C$ and $D), A$ and $B$, GFAP immunostaining and IGFBP2 in situ hybridization is shown in low- $(A)$ and high- $(B)$ magnification double-exposure photomicrographs superimposing a bright-field image focused on the tissue plane and a red-filtered dark-field image focused on the emulsion plane. Exposed silver grains in the emulsion overlying the tissue appear red using this technique. The GFAP immunostain is brown, and cells are counterstained with cresyl violet. GFAP is detected in the radial Bergmann fibers (arrowheads) traversing the molecular layer ( $\mathrm{ml}$ ). Granule cells, stained purple, are seen positioned along these fibers. IGFBP2 mRNA hybrids are concentrated in cells from which these fibers arise that are faintly GFAP positive (solid arrows in $B$ ) and located next to the large Purkinje cells (open arrows). IGFBP2 mRNA is highly abundant in the meninges covering the cerebellar surface, seen in the upper left corner of $A$. $C$ and $D$, Vimentin immunostaining was used to identify glial cells of the retina and combined with in situ hybridization for IGF-I $(C)$ and IGFBP2 $(D)$ mRNAs. These are double-exposure photomicrographs combining bright-field and epifluorescence images so that the hybridization signal is visualized as green grains. Vimentin-positive astrocytes and their processes surround fascicles of ganglion cell axons in the nerve fiber layer $(n f)$. IGF-I mRNA $(C)$ is concentrated in ganglion cell bodies $($ solid arrows), stained violet-blue, and perhaps in their dendrites extending some distance into the inner plexiform layer (ip). IGFBP2 mRNA ( $D$ ) is concentrated in the vimentin-positive cells of the nerve fiber and ganglion cell layers and in faintly vimentin-positive cells located in the inner nuclear layer (in) from which the retinal radial fibers appear to originate (open arrows). Scale bars: $25 \mu \mathrm{m}$ for $A ; 62 \mu \mathrm{m}$ for $B ; 37 \mu \mathrm{m}$ for $C$ and $D$.

provides further support for the view that IGF-I action is local. IGFBP2 is presumably secreted from these neuroglia in vivo as it is secreted from neuroglia in vitro (Han et al., 1988; Loret et al., 1991; Olson et al., 1991). IGFBP2 present in the extracellular space surrounding the cells from which it is released may bind the IGF-I secreted from Purkinje and retinal ganglion cells and thus prevent IGF-I from effectively binding to astroglial IGF-I receptors-and potentially deflecting or diverting its action toward growing dendritic or axonal processes. Alternatively, it is possible that IGFBP2 is not free in the extracellular space but is distributed upon the surface of cells or cell processes bearing integrin receptors, and in this context may target IGF-I to par- ticular membrane sites and thus regulate IGF-I's interaction with specific targets. Resolution of these important issues requires immunocytochemical analysis of IGFBP2 and IGF-I localization at the ultrastructural level.

Bergmann and Müller cells have been intensively studied in their role as radial glia-specialized astroglial cells involved in the guidance of migrating neurons to their mature neuroanatomical destination (Rakic, 1981; Hatten, 1990). In the cerebellar cortex, Bergmann fibers form a scaffolding along which granule cells move from external to internal granule cell layers (see Fig. 4A), and in the retina, Müller cell processes are thought to guide neuroblasts from the germinal zone to their positions 
in the laminar neural retina. Recently, it has been suggested that Purkinje cells may influence Bergmann glial cell metabolism, as reflected by glycerol-3-phosphate dehydrogenase immunoreactivity (Fisher and Mullen, 1988). The present observations provide additional support for the existence of specific biochemical relationships between Bergmann and Müller glia and nonmigrating neurons during development. The coordinated expression of IGF-I by projection neurons and IGFBP 2 by contiguous radial glia seems unlikely to be associated with the glial cclls' role in guidance of neural migration. While in the cerebellar cortex the timing of IGF system gene expression parallels the course of granule cell migration fairly well, this is not the case in the retina, where migration is over at the time of IGF-I peak expression, nor is it true in other brain regions, such as the thalamus, where IGF-I and IGFBP2 expression is similarly coordinated during postnatal development (W.-H. Lee, K. M. Michels, and C. A. Bondy, unpublished observations). Furthermore, IGFBP2 mRNA is also expressed by retinal nerve astrocytes that are not radial glia and are not implicated in neuronal migration. The primary interaction during the process of neural migration appears to be between radial glial fibers and migratory neurons (Rakic, 1981; Hatten, 1990), whereas we have presented evidence for a developmental relationship between postmigratory projection neurons and adjacent astroglia, which may or may not also be radial glia.

IGF-I promotes DNA synthesis in cultured astroglia, and exogenous IGFBP2 inhibits this effect (Han et al., 1988). It is possible that during the course of normal development, in situations where astroglia are localized immediately adjacent to IGF-I-producing neurons, astroglial IGFBP2 production is stimulated in order to shield the glial cells against IGF-I's mitogenic effects-so that the glia can continue to perform their differentiated functions. In the setting of CNS injury, such as vascular infarction or toxic demyelination where there is a reactive gliosis, or proliferation of astrocytes, IGF-I is produced in abundance by involved astrocytes (Komoly et al., 1992; Lee et al., 1992). IGFBP2, however, is not expressed by astrocytes in this situation (Lee et al., 1992), suggesting that IGF-I, in the absence of IGFBP2, may stimulate astrocytic proliferation.

In order to understand the autocrine/paracrine roles of growth factors in cell-cell interactions during the genesis and differentiation of the CNS, it is essential to have a clear picture of which cells are producing the secreted growth factors and which cells are expressing the receptor(s) and binding proteins in vivoand to know when these components are expressed, with respect to different developmental processes. Our studies are aimed at elucidating the spatiotemporal framework in which IGF-I is involved in cell-cell interactions during differentiation of the nervous system. This study has established that IGFBP2 gene expression is temporally and anatomically coordinated with that of IGF-I during cerebellar and retinal development, thus implicating IGFBP2 as a key modulator of IGF-I action in CNS development.

\section{References}

Aguado F, Sanchez-Franco F, Cacidedo L, Fernandez T, Rodrigo J, Martinez-Murillo R (1992) Subcellular localization of insulin-like growth factor I in Purkinje cells of the adult rat: an immunocytochemical study. Neurosci Lett 135:171-174.

Andersson IK, Edwall D, Norstedt G, Rozell B, Skottner A, Hansson H-A (1988) Differing expression of insulin-like growth factor I in the developing and adult rat cerebellum. Acta Physiol Scand 132: $167-173$.
Barde YA (1989) Trophic factors and neuronal survival. Neuron 2: 1525-1534.

Bartlett WP, Li X-S, Williams M, Benkovic S (1991) Localization of insulin-like growth factor-I mRNA in murine central nervous system during postnatal development. Dev Biol 147:239-250.

Beck F, Samani NJ, Penschow JD, Thorley B, Tregear GW, Coghlan JP (1987) Histochemical localization of IGF-I and -II mRNA in the developing rat embryo. Development 101:175-184.

Bignami A, Dahl D (1973) Differentiation of astrocytes in the cerebellar cortex and pyramidal tracts of the newborn rat. Brain Res 49: 393-402.

Bohannon NJ, Corp ES, Wilcox BJ, Figlewicz DP, Dorsa DM, Baskin DG (1988) Localization of binding sites for IGF-I in the rat brain by quantitative autoradiography. Brain Res 444:205-213.

Bondy CA (1991) Transient IGF-I gene expression during the maturation of functionally-related central projection neurons. J Neurosci 11:3442-3455.

Bondy CA, Werner H, Roberts CT Jr, LeRoith D (1990) Cellular pattern of insulin-like growth factor-I (IGF-I) and type I IGF receptor gene expression in early organogenesis: comparison with IGF-II gene expression. Mol Endocrinol 4:1386-1398.

Bondy CA, Werner H, Roberts CT Jr, LeRoith D (1992) The cellular pattern of type-I IGF receptor gene expression during the maturation of the rat brain: comparison with IGF-I and IGF-II. Neuroscience 46:909-923.

Brown AL, Chiariotti L, Orlowski CC, Mehlman T, Burgess WH, Ackerman EJ, Bruni CB, Rechler MM (1989) Nucleotide sequence and expression of a cDNA clone encoding a fetal rat binding protein for insulin-like growth factors. J Biol Chem 264:5148-5154.

Chin E, Zhou J, Bondy CA (1992) Anatomical relationships in the pattern of IGF-I, IGFBP-1 and IGF-I receptor gene expression in the rat kidney. Endocrinology 130:3237-3245.

Clemmons DR (1990) Insulin-like growth factor binding proteins. Trends Endocrinol Metab 1:412-417.

Czech MP (1989) Signal transmission by the insulin-like growth factors. Cell 59:235-238.

Das GP (1976) Differentiation of Bergmann glia cells in the cerebellum: a Golgi study. Brain Res 110:199-213.

Daughaday WH, Rotwein P (1989) Insulin-like growth factors I and II. Peptide, messenger ribonucleic acid and gene structures, serum, and tissue concentrations. Endocrinol Rev 10:68-91.

De Mellow JSM, Baxter RC (1988) GH dependent IGFBP both inhibits and potentiates IGF-I stimulated DNA synthesis in skin fibroblasts. Biochem Biophys Res Commun 156:199-204.

Dixon RG, Eng LE (1981) Glial fibrillary acidic protein in the retina of the developing albino rat. J Comp Neurol 195:305-321.

Elgin RG, Busby WH, Clemmons DR (1987) An insulin like growth factor binding protein enhances the biological response to IGF-I. Proc Natl Acad Sci USA 84:3313-3318.

Fisher M, Mullen RJ (1988) Neuronal influence on glial enzyme expression: evidence from chimeric mouse cerebellum. Neuron 1:151157.

Girbau M, Bassas L, Alemany J, De Pablo F (1989) In situ autoradiography and ligand-dependent tyrosine kinase activity reveal insulin receptors and insulin-like growth factor receptors in pancreatic chicken embryos. Proc Natl Acad Sci USA 86:5868-5872.

Han VKM, Lauder JM, D'Ercole AJ (1988) Rat astroglial somatomedin/insulin-like growth factor binding proteins: characterization and evidence of biological function. J Neurosci 8:3135-3143.

Hansson H-A, Holmgren A, Norstedt G, Rozell B (1989) Changes in the distribution of IGF-I, thioredoxin, thioredoxin reductase and ribonucleotide reductase during the development of the retina. Exp Eye Res 48:411-420.

Hatten ME (1990) Riding the glial monorail: a common mechanism for glial-guided neuronal migration in different regions of the developing mammalian brain. Trends Neurosci 13:179-184.

Hsu S-M, Raine L, Fanger H (1981) Use of avidin-biotin-peroxidase complex $(\mathrm{ABC})$ in immunoperoxidase techniques: A comparison between $\mathrm{ABC}$ and unlabeled antibody (PAP) procedures. $J$ Histochem Cytochem 29:577-580.

Jones JI, D'Ercole AJ, Camacho-Hubner C, Clemmons DR (1991) Phosphorylation of IGF-binding protein-1 in cell culture and in vivo: effects on affinity for IGF-I. Proc Natl Acad Sci USA 88:7481-7485.

Komoly S, Hudson LD, Webster HD, Bondy CA (1992) Insulin-like growth factor I gene expression is induced in astrocytes during experimental demyelination. Proc Natl Acad Sci USA 89:1894-1898. 
Lee W-H, Clemens JA, Bondy CA (1992) Insulin-like growth factors in the response to cerebral ischemia. Mol Cell Neurosci 3:36-43.

LeRoith D, Roberts CT Jr, Werner H, Bondy C, Raizada M, Adamo $M$ (in press) Insulin-like growth factors in the brain. In: Neurotrophic factors (Fallon $\mathrm{JH}$, Loughlin SE, eds), in press.

Lesnıak MA, Hill JM, Kiess W, Rojeski M, Pert CB, Roth J (1988) Receptors for insulin-like growth factors I and II: autoradiographic localization in rat brain and comparison to receptors for insulin. Endocrinology 123:2089-2099.

Ling T, Mitrofanis J, Stone J (1989) Origin of retinal astrocytes in the rat: evidence of migration from the optic nerve. J Comp Neurol 286: $345-352$.

Loret C, Janet T, Labourdette G, Schneid H, Binoux M (1991) FGFs stimulate IGFBP synthesis without affecting IGF synthesis in rat astroblasts in primary culture. Glia 4:378-383.

Lowe WL Jr, Lasky SR, LeRoith D, Roberts CT Jr (1988) Distribution and regulation of rat IGF-I mRNA encoding alternative carboxyterminal E-peptides: evidence for differential processing and regulation in liver. Mol Endocrinol 2:528-535.

Ocrant I, Valentino KL, King MG, Wimpy TH, Rosenfeld RG, Baskin DG (1989) Localization and structural characterization of IGF receptors in mammalian retina. Endocrinology 125:2407-2413.
Olson JA, Shiverick KT, Oligive S, Buhi WC, Raizada MK (1991) Developmental expression of rat IGFBP2 by astrocytic glial cells in culture. Endocrinology 129:1066-1074.

Ooi $G$ (1990) Insulin-like growth factor-binding proteins (IGFBPs): more than just 1, 2, 3. Mol Cell Endocrinol 71:C39-C43.

Rakic P (1981) Neuronal-glial interactions during brain development. Trends Neurosci 4:184-187.

Rechler MM, Nissley SP (1990) Insulin-like growth factors. Handb Exp Pharmacol 95:263-367.

Stylianopoulou F, Herbert J, Soares MB, Efstratiadis A (1988) Expression of the insulin-like growth factor II gene in the choroid plexus and the leptomeninges of the adult rat central nervous system. Proc Natl Acad Sci USA 85:141-145.

Werner H, Woloschek M, Adamo M, Shen-Orr Z, Roberts CT Jr, LeRoith D (1989) Developmental regulation of the rat IGF-I receptor gene. Proc Natl Acad Sci USA 86:7451-7455.

Wood TL, Brown AL, Rechler MM, Pintar JE (1990) The expression pattern of an insulin-like growth factor (IGF)-binding protein gene is distinct from IGF-II in the midgestational rat embryo. Mol Endocrinol 4:1257-1263. 